\title{
Complex formation between platelet-derived growth factor receptor $\beta$ and transforming growth factor $\beta$ receptor regulates the differentiation of mesenchymal stem cells into cancer- associated fibroblasts
}

\author{
Kaori Aoto ${ }^{1}$, Kousei Ito ${ }^{1}$ and Shigeki Aoki ${ }^{1}$ \\ ${ }^{1}$ Laboratory of Biopharmaceutics, Graduate School of Pharmaceutical Sciences, Chiba University, Inohana 1-8-1, Chuo-ku, \\ Chiba-city, Chiba 260-8675, Japan \\ Correspondence to: Shigeki Aoki, email: aokishigeki@chiba-u.jp \\ Keywords: cancer-associated fibroblast; PDGFRß; TGFß signaling; mesenchymal stem cell \\ Received: June 26, $2018 \quad$ Accepted: September 04, $2018 \quad$ Published: September 25, 2018 \\ Copyright: Aoto et al. This is an open-access article distributed under the terms of the Creative Commons Attribution License 3.0 \\ (CC BY 3.0), which permits unrestricted use, distribution, and reproduction in any medium, provided the original author and source \\ are credited.
}

\section{ABSTRACT}

Cancer-associated fibroblasts (CAFs) have recently gained attention as potent targets in cancer therapy because they are a crucial component of the tumor microenvironment and promote the growth and invasion of cancer cells. CAFs differentiate from fibroblasts, mesenchymal stem cells (MSCs), epithelial cells, and other cell types in response to transforming growth factor $\beta$ (TGF $\beta$ ) stimulation. The drugs tranilast, imatinib, and pirfenidone reportedly inhibit the differentiation of such cells into CAFs; however, it is unclear how they regulate TGF $\beta$ signaling. Here, we differentiated MSCs into CAFs in vitro and investigated which drugs suppressed this differentiation. Based on these results, we focused on platelet-derived growth factor (PDGF) receptor $\beta$ (PDGFR $\beta$ ) as a key molecule in the initiation of TGF $\beta$ signaling. PDGFR $\beta$ transmitted TGF $\beta$ signaling in MSCs by forming a complex with TGF $\beta$ receptor (TGF $\beta R$ ) independently of stimulation with its well-known ligand PDGF. Inhibitors of the differentiation of MSCs into CAFs attenuated complex formation between PDGFR $\beta$ and TGF $\beta$. Moreover, PDGF stimulated PDGFR $\beta$ to a lesser extent in CAFs than in MSCs. This study indicates that PDGFR $\beta$ and TGF $\beta$-TGF $\beta R$ signaling cooperatively promote the differentiation of MSCs into CAFs in tumor microenvironments independently of canonical PDGF-PDGFR signaling. We propose that blockade of the interaction between PDGFR $\beta$ and TGF $\beta R$ is a potential strategy to prevent TGF $\beta$ mediated differentiation of MSCs into CAFs.

\section{INTRODUCTION}

Tumor tissues are composed of cancer cells and the surrounding microenvironments. Tumor microenvironments contain vascular lymphatic networks, fibroblastic cells, inflammatory immune cells, mesenchymal stem cells (MSCs), and extracellular matrices [1, 2]. Much data acquired in vitro and in vivo suggest that fibroblastic cells are important for cancer progression, in addition to the tumor stroma [3]. In particular, cancer-associated fibroblasts (CAFs), a subpopulation of fibroblastic cells, promote tumor growth and progression [4]. CAFs accelerate remodeling of the extracellular matrix, angiogenesis, and recruitment of inflammatory immune cells, and also secrete growth factors that increase the proliferation of cancer cells $[5,6]$. In addition, CAFs have important functions in tumor microenvironments; therefore, effective anti-cancer therapies that target CAFs in addition to cancer cells must be developed.

CAFs differentiate from fibroblasts, MSCs, epithelial cells, endothelial cells, and other cell types in tumor microenvironments [7]. Expression of $\alpha$-smooth muscle actin ( $\alpha$ SMA), N-cadherin, fibroblast surface protein, fibroblast 
activation protein, and vimentin is much higher in CAFs than in normal fibroblasts [8]; however, there is no known specific marker protein of CAFs. Transforming growth factor $\beta$ (TGF $\beta)$ is a cytokine mainly released from cancer cells that plays an important role in differentiation into CAFs $[9,10]$. Smad proteins are phosphorylated upon activation of TGF $\beta$ receptor (TGF $\beta R$ ) by its specific ligand TGF $\beta$ [11]. Phosphorylated Smad proteins subsequently translocate into the nucleus and function as transcription factors to induce expression of CAF-related genes, including $\alpha \mathrm{SMA}$ [11].

There are two isoforms of platelet-derived growth factor (PDGF) receptors (PDGFRs): PDGFR $\alpha$ and PDGFR $\beta$ [12]. PDGFRs control the functions of MSCs via remodeling the actin cytoskeleton, inducing cell migration by activating phosphoinositide 3-kinase (PI3K) and phospholipase $\mathrm{C}-\gamma$, and promoting cell growth by activating the mitogen-activated protein kinase (MAPK) pathway and Src [13]. Furthermore, PDGFRs stimulate the growth of squamous cell carcinomas, such as renal cell, ovarian, and prostate cancers [14], promote vascularization by recruiting pericytes to blood vessels within tumor tissues [15], and facilitate lymphatic regeneration in fibrosarcomas [16]. All these effects exacerbate tumor pathology. In addition, PDGFR expression in fibroblastic cells within the microenvironment of breast cancer is positively correlated with the pathological grade, HER2 expression, and shortening of progression-free survival [17]. Stimulation with PDGF, the ligand of PDGFRs, is required for recruitment of fibroblastic cells to tumor tissues [13]. In summary, PDGFRs promote cancer malignancy via various intracellular mechanisms.

Although a clinical strategy that directly suppresses the functions of CAFs has not been approved, several pharmaceuticals that are already clinically used have been suggested to inhibit fibroblast activation, differentiation into CAFs, and growth of CAFs in the laboratory. Among these pharmaceuticals, tranilast, which inhibits release of chemical mediators such as histamines from mast cells and is clinically used as an anti-allergy medication [18], suppresses the growth of CAFs and their secretion of TGF $\beta$ in mice bearing lymphosarcomas or Lewis lung carcinomas [19]. Imatinib, a tyrosine kinase inhibitor (TKI) that binds to $\mathrm{c}-\mathrm{ABL}, \mathrm{BCR}-\mathrm{ABL}$, and c-KIT and is clinically used to treat chronic myeloid leukemia and gastrointestinal stromal tumors [20], prevents fibrosis in a mouse model of bleomycin-induced lung fibrosis [21] and reduces $\alpha$ SMA expression in CAFs derived from colon metastatic lesions of patients [22]. Pirfenidone, which inhibits the growth and activation of fibroblasts and is clinically used to treat idiopathic pulmonary fibrosis [23], suppresses the differentiation of human pulmonary fibroblasts into myofibroblasts upon exposure to TGF $\beta$ [24]. Although these drugs have been suggested to inhibit differentiation into CAFs by reducing production of TGF $\beta$ and phosphorylation of Smad proteins downstream of TGF $\beta$ signaling [19, 24], it is unclear how they regulate TGF $\beta$ signaling.
Inhibition of the differentiation of normal cells, including MSCs, into CAFs within tumor microenvironments is a potential anti-cancer strategy. Therefore, we sought to elucidate the detailed molecular mechanism by which TGF $\beta$ stimulation induces the differentiation of these cells into CAFs and how the aforementioned drugs capable of suppressing this differentiation interfere with TGF $\beta$ signaling. Here, we differentiated MSCs into CAFs via TGF $\beta$ stimulation in vitro and investigated how this differentiation was suppressed by various drugs. We demonstrated that PDGFR $\beta$ and TGF $\beta$ signaling cooperatively promote the differentiation of MSCs into CAFs upon TGF $\beta$ exposure independently of PDGF stimulation and that complex formation between PDGFR $\beta$ and TGF $\beta$ R is important for this differentiation.

\section{RESULTS}

\section{MSCs differentiate into CAFs upon TGF $\beta$ stimulation}

Among the various cell types that reportedly give rise to CAFs, we focused on MSCs, which can differentiate into various cell types including osteoblastic cells, adipocytes, muscle cells, and CAFs [25]. We first investigated the differentiation of murine MSC-like ST2 cells into CAFs upon exposure to TGF $\beta$. ST2 cells became spindle-shaped following TGF $\beta$ stimulation (Figure 1A). mRNA expression of $\alpha \mathrm{SMA}, \mathrm{N}$-cadherin, and vimentin, which are markers of differentiation into CAFs, was significantly increased in TGF $\beta$-treated ST2 cells, and these increases were sustained for 1 week (Figure 1B). Similarly, mRNA expression of $\alpha \mathrm{SMA}$ and N-cadherin was increased in human primary MSCs treated with TGF $\beta$ (Figure 1C). Moreover, the intracellular level of $\alpha$ SMA protein was increased in ST2 cells and human MSCs exposed to TGF $\beta$ (Figures 1D and 1E). These results confirm that ST2 cells and human MSCs differentiated into CAF-like cells upon TGF $\beta$ stimulation.

CAFs reportedly also release TGF $\beta$ and increase the invasive ability of cancer cells in tumor microenvironments [7]. mRNA expression (Figures $1 \mathrm{~F}$ and $1 \mathrm{G}$ ) and secretion (Figure $1 \mathrm{H}$ ) of TGF $\beta$ were increased in TGF $\beta$-stimulated ST2 cells (Figures 1F and $1 \mathrm{H}$ ) and human MSCs (Figure $1 \mathrm{G}$ ). Next, we evaluated the effect of CAFs on the invasive ability of cancer cells. Upon co-culture in a transwell plate, mRNA expression of TGF $\beta$ was higher in mouse melanoma B16 cells cocultured with TGF $\beta$-stimulated ST2 cells than in those co-cultured with non-stimulated ST2 cells (Figure 1I). Moreover, the invasive ability of the former cells was higher than that of the latter cells (Figure 1J). These results indicate that ST2 cells differentiate into CAFs upon TGF $\beta$ treatment and that these CAFs increase the malignancy of cancer cells. 
PDGFRs may be involved in the suppressive effects of various drugs on differentiation into CAFs

Tranilast, pirfenidone, and imatinib are reported to suppress differentiation into CAFs, as described in the
Introduction. We investigated whether treatment with these drugs inhibited the increase in expression of CAF markers upon TGF $\beta$ stimulation in our experimental conditions. Exposure to any of these three drugs suppressed the increases in mRNA expression of $\alpha \mathrm{SMA}$ and TGF $\beta$ in TGF $\beta$-treated ST2 cells (Figures 2A and 2B).
A

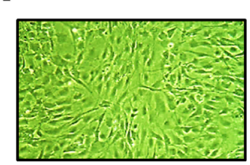

Control

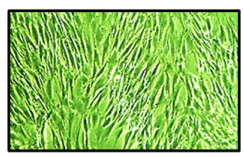

TGF $\beta$
B

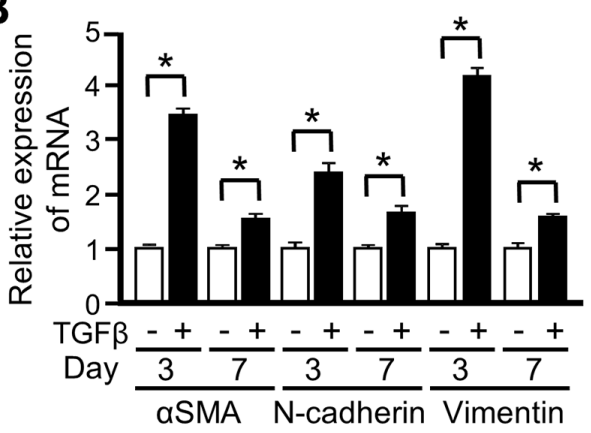

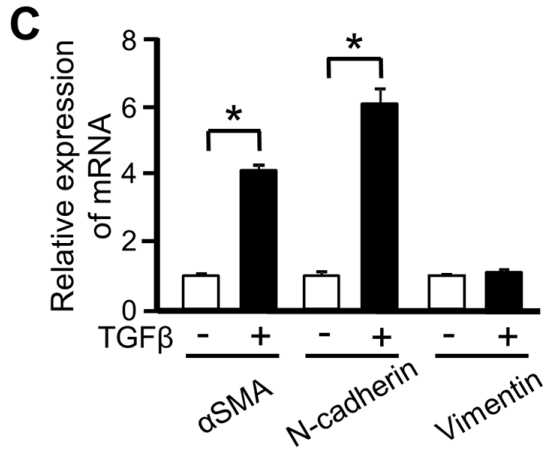

G
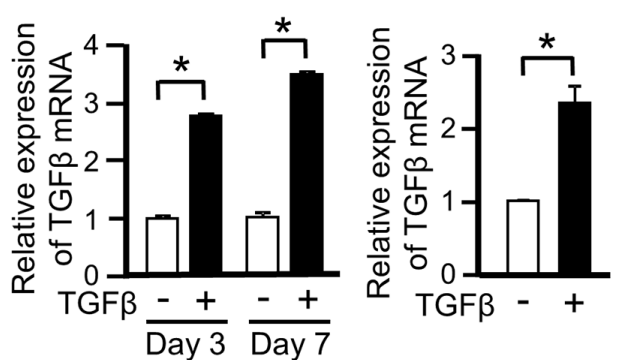
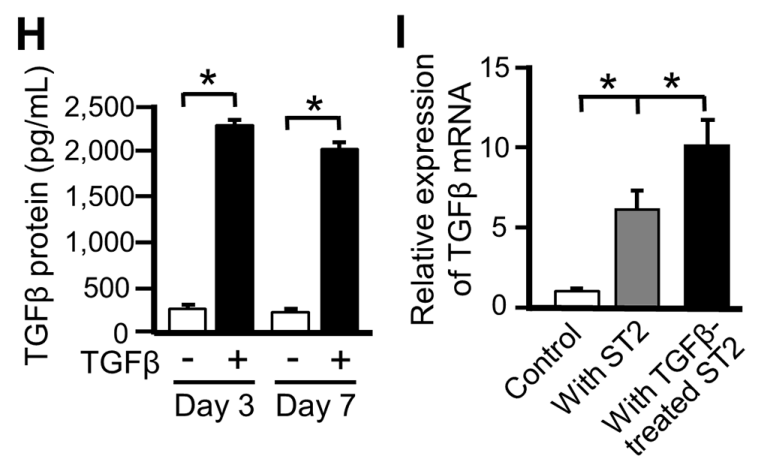

J

$24 \mathrm{~h}$

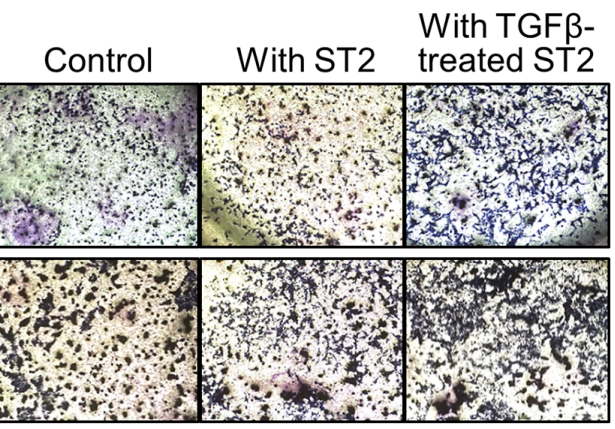

Figure 1: Mesenchymal stem cells (MSCs) differentiate into cancer-associated fibroblasts (CAFs) upon TGF stimulation. (A) Microscopic images of ST2 cells after stimulation with TGF $\beta(10 \mathrm{ng} / \mathrm{mL})$ for 48 h. Magnification $\times 100$. (B, C) Quantitative RT-PCR analysis was performed to measure mRNA expression of the CAF markers $\alpha$ SMA, N-cadherin, and vimentin in ST2 cells treated with TGF $\beta$ for 3 and 7 days (B) and in human MSCs treated with TGF $\beta$ for 3 days (C). Each bar represents the mean \pm SD $(\mathrm{N}=3),{ }^{*} \mathrm{P}<0.05$. (D, E) Immunostaining of $\alpha \mathrm{SMA}$ (green) was performed in ST2 cells (D) and human MSCs (E) treated with TGF $\beta$ for $48 \mathrm{~h}$. Each scale bar indicates $20 \mu \mathrm{m}$. Nuclei were stained with TO-PRO-3 (blue). (F, G) Quantitative RT-PCR analysis was performed to measure mRNA expression of TGF $\beta$ in ST2 cells treated with TGF $\beta$ for 3 and 7 days (F) and in human MSCs treated with TGF $\beta$ for 3 days (G). Each bar represents the mean $\pm \mathrm{SD}(\mathrm{N}=3),{ }^{*} \mathrm{P}<0.05$. (H) Secretion of TGF $\beta$ by ST2 cells treated with TGF $\beta$ for 3 and 7 days was assessed by an ELISA. Each bar represents the mean $\pm \mathrm{SE}(\mathrm{N}=3),{ }^{*} \mathrm{P}<0.05$. (I) B16 cells were co-cultured with non-treated or TGF $\beta$-treated ST2 cells in a transwell plate for 7 days, and mRNA expression of TGF $\beta$ in B16 cells was measured by quantitative RT-PCR analysis. Each bar represents the mean $\pm \mathrm{SD}(\mathrm{N}=3),{ }^{*} \mathrm{P}<0.05$. (J) B16 cells were co-cultured with non-treated or TGF $\beta$-treated ST2 cells for 24 or $48 \mathrm{~h}$, and invaded B16 cells were stained with crystal violet (deep blue). 
Next, we evaluated whether cromoglicate, another inhibitor of chemical mediator release, and dasatinib and bosutinib, which are TKIs, also inhibited the differentiation of ST2 cells into CAFs. Exposure to these three drugs did not suppress the increases in mRNA expression of $\alpha \mathrm{SMA}$ and TGF $\beta$ in TGF $\beta$-stimulated ST2 cells (Figures 2C and $2 \mathrm{D})$. These results suggest that the main pharmacological actions of tranilast and imatinib are not directly involved in the suppression of differentiation into CAFs.

Imatinib and these two second-generation TKIs (dasatinib and bosutinib) target different kinases. Puttini et al. investigated the suppressive effects of bosutinib and imatinib on growth of leukemia cells expressing Bcr-Abl, Ba/F3 cells expressing PDGFR $\beta$, and gastrointestinal stromal tumor cells expressing c-KIT, and calculated their $\mathrm{IC}_{50}$ values [26]. They estimated that the $\mathrm{IC}_{50}$ values of imatinib and bosutinib in $\mathrm{Ba} / \mathrm{F} 3$ cells expressing PDGFR $\beta$ are 3.4 and $370 \mathrm{nmol} / \mathrm{L}$, respectively, suggesting that imatinib strongly inhibits PDGFR $\beta$ [26]. Therefore, we hypothesized that PDGFRs, including PDGFR $\beta$, induce differentiation into CAFs in cooperation with TGF $\beta$ signaling.

\section{PDGFR $\beta$ is involved in the differentiation of MSCs into CAFs}

There are two subtypes of PDGFRs: PDGFR $\alpha$ and PDGFR $\beta$ [12]. We quantified the absolute expression levels of these two PDGFR subtypes in ST2 cells and human MSCs, and evaluated the changes in their expression upon TGF $\beta$ stimulation. mRNA expression
A

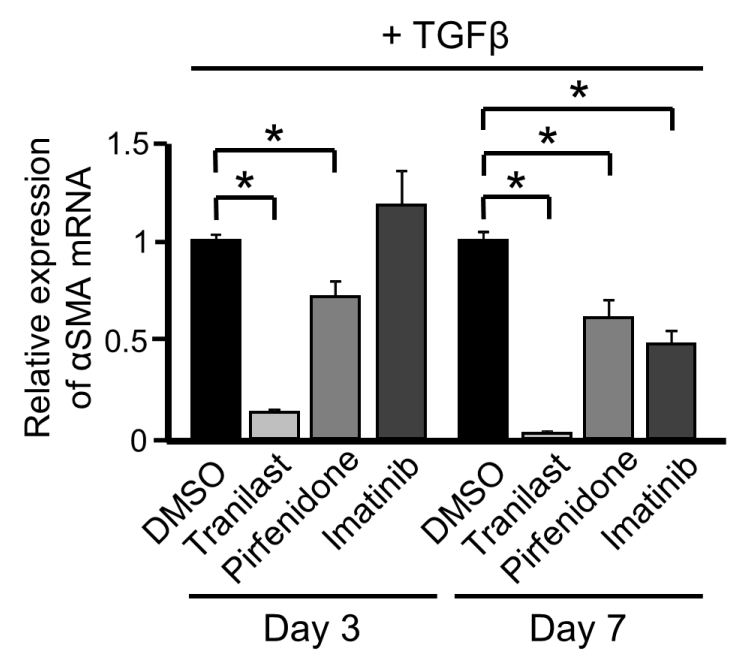

C

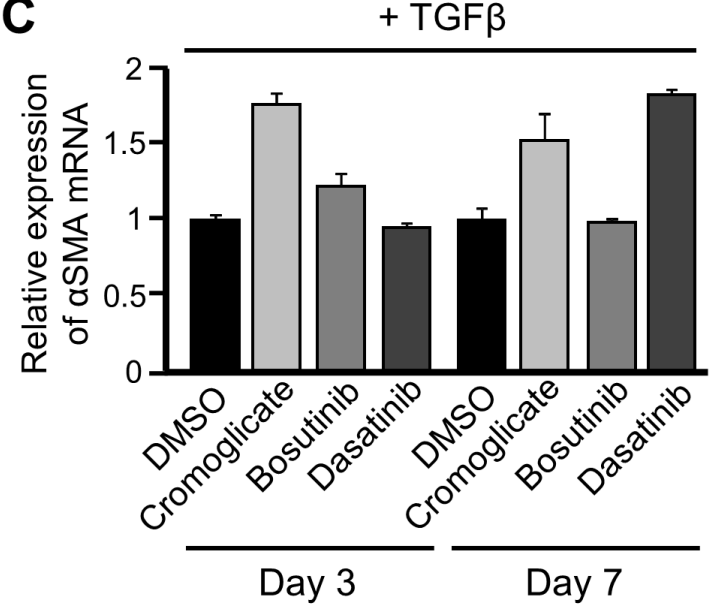

B

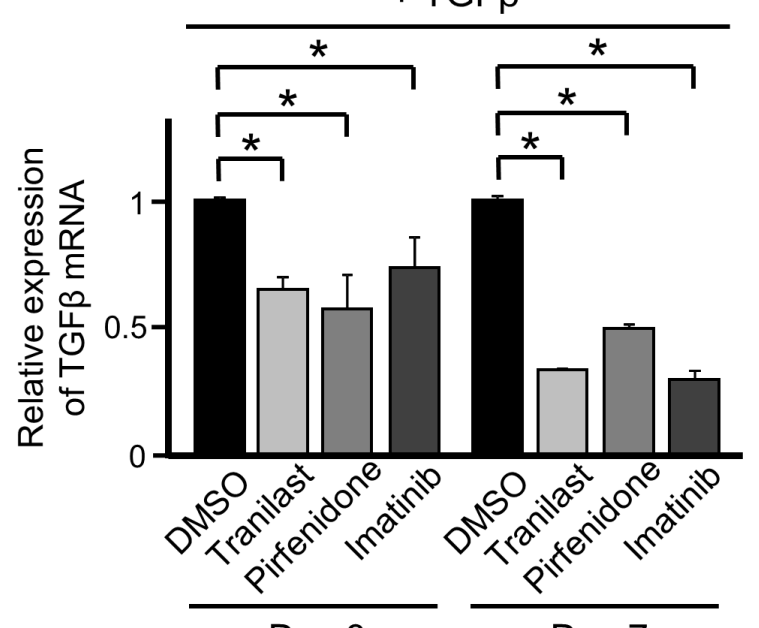

Day 3

Day 7

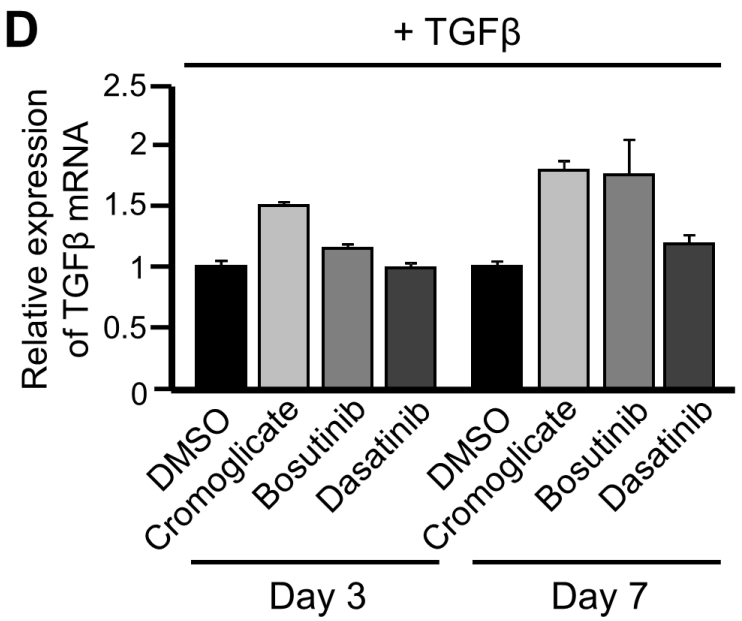

Figure 2: PDGFRs may be involved in the suppressive effects of various drugs on differentiation into cancer-associated fibroblasts (CAFs). (A, B) ST2 cells were pre-treated with tranilast $(100 \mu \mathrm{M})$, pirfenidone $(0.2 \mathrm{mg} / \mathrm{mL})$, or imatinib $(10 \mu \mathrm{M})$ for $1 \mathrm{~h}$ and then stimulated with TGF $\beta(10 \mathrm{ng} / \mathrm{mL})$ for 3 and 7 days. Quantitative RT-PCR analysis was performed to measure mRNA expression of $\alpha$ SMA (A) and TGF $\beta$ (B). Each bar represents the mean $\pm \mathrm{SD}(\mathrm{N}=3),{ }^{*} \mathrm{P}<0.05$. (C, D) ST2 cells were pre-treated with cromoglicate $(100 \mu \mathrm{M})$, bosutinib $(100 \mathrm{nM})$, or dasatinib $(10 \mathrm{nM})$ for $1 \mathrm{~h}$ and then stimulated with TGF $\beta$ for 3 and 7 days. Quantitative RT-PCR analysis was performed to measure mRNA expression of $\alpha \mathrm{SMA}(\mathrm{C})$ and TGF $\beta$ (D). Each bar represents the mean $\pm \mathrm{SD}(\mathrm{N}=3)$. 
of PDGFR $\beta$ was higher than that of PDGFR $\alpha$ in ST2 cells, and TGF $\beta$ stimulation significantly increased mRNA expression of PDGFR $\beta$, but decreased that of PDGFR $\alpha$ (Figure 3A). Although basal mRNA expression of PDGFR $\alpha$ and PDGFR $\beta$ did not differ in human MSCs, TGF $\beta$ stimulation significantly increased mRNA expression of PDGFR $\beta$, similar to its effect in ST2 cells (Figure $3 \mathrm{~B}$ ). These results suggest that PDGFR $\beta$ is involved in the differentiation of MSCs into CAFs.

We further evaluated the involvement of PDGFR $\beta$ in the differentiation of MSCs into CAFs by depleting its expression. Transfection of PDGFR $\beta$-targeting siRNA markedly reduced mRNA and protein expression of PDGFR $\beta$ in ST2 cells (Figure 3C). The increases in mRNA and protein expression of $\alpha$ SMA upon TGF $\beta$ stimulation were abrogated in PDGFR $\beta$-knockdown ST2 cells (Figures 3D and 3E). In addition, knockdown of PDGFR $\beta$ attenuated the increase in the invasive ability of B16 cells upon co-culture with TGF $\beta$-treated ST2 cells (Figure 3F). These results indicate that PDGFR $\beta$ and TGF $\beta$ signaling cooperatively promote the differentiation of MSCs into CAFs.

\section{PDGF-PDGFR $\beta$ signaling does not affect the differentiation of MSCs into CAFs}

PDGFR $\beta$ is autophosphorylated in response to its well-known ligand PDGF-BB, leading to activation of downstream signaling molecules in the PI3K and MAPK pathways [27]. Therefore, we evaluated whether PDGF stimulation regulates the differentiation of ST2 cells into CAFs by inducing phosphorylation of PDGFR $\beta$. Although PDGF-BB stimulation induced phosphorylation of PDGFR $\beta$ (Figure 4A) and promoted the proliferation of ST2 cells (data not shown), it decreased, rather than increased, mRNA expression of $\alpha$ SMA and TGF $\beta$ (Figures 4B and 4C). Moreover, exposure to CP673451, which inhibits phosphorylation of PDGFR $\beta$, enhanced, rather than suppressed, the increase in mRNA expression of aSMA in TGF $\beta$-treated ST2 cells (Figures 4D and 4E). In addition, TGF $\beta$ stimulation, which is necessary for differentiation into CAFs, did not induce phosphorylation of PDGFR $\beta$ in ST2 cells (Figure 4F). These results indicate that PDGFR $\beta$ is not phosphorylated during the differentiation of MSCs into CAFs upon TGF $\beta$ stimulation and that this differentiation occurs independently of the classical PDGF-PDGFR signaling cascade.

\section{PDGFR $\beta$ induces the differentiation of MSCs into CAFs by interacting with TGF $\beta R$}

TGF $\beta$ transmits intracellular signals by binding to the heterotetramer TGF $\beta$, which is composed of two type I and two type II receptors [28]. Given that inhibition of PDGFR $\beta$ phosphorylation did not perturb the differentiation of MSCs into CAFs, we investigated whether PDGFR $\beta$ transmits TGF $\beta$-TGF $\beta$ R signaling by interacting with TGF $\beta$ R. Immunoprecipitation analyses using an anti-PDGFR $\beta$ antibody indicated that complex formation between PDGFR $\beta$ and TGF $\beta$ R was higher at $1 \mathrm{~h}$ after TGF $\beta$ stimulation than prior to stimulation and that this effect was sustained at $48 \mathrm{~h}$ after stimulation (Figure 5A). In addition, no further complex formation between PDGFR $\beta$ and TGF $\beta$ R was observed when CAFs that had differentiated from ST2 cells in response to TGF $\beta$ were re-stimulated with TGF $\beta$ (Figure 5A). These results suggest that the interaction between PDGFR $\beta$ and TGF $\beta R$ is important for initiation of the differentiation of MSCs into CAFs and that this complex is maintained in CAFs.

We evaluated whether exposure to tranilast, imatinib, and pirfenidone, which suppress differentiation into CAFs, decreased complex formation between PDGFR $\beta$ and TGF $\beta$ R in ST2 cells. The increase in complex formation between PDGFR $\beta$ and TGF $\beta R$ was attenuated in ST2 cells pre-treated with each drug for $12 \mathrm{~h}$ and then exposed to TGF $\beta$ for $1 \mathrm{~h}$ (Figures 5B and $5 \mathrm{C})$. This finding suggests that these drugs suppress the differentiation of MSCs into CAFs by physicochemically preventing the interaction between PDGFR $\beta$ and TGF $\beta$ R.

\section{PDGFR $\beta$ contributes to the activation of non- canonical TGF $\beta$ signaling}

Binding of TGF $\beta$ to its receptor promotes phosphorylation of the transcription factors $\operatorname{Smad} 2 / 3$, and then phosphorylated Smad2/3 translocate to the nucleus and induce expression of their target genes, including $\alpha$ SMA [28]. We evaluated whether PDGFR $\beta$ affects activation of $\mathrm{Smad} 2 / 3$ downstream of TGF $\beta$ signaling. The level of Smad2/3 phosphorylation did not significantly differ between control and PDGFR $\beta$-knockdown ST2 cells following TGF $\beta$ exposure (data not shown), indicating that PDGFR $\beta$ does not directly affect activation of $\mathrm{Smad} 2 / 3$ upon TGF $\beta$ stimulation.

In addition to the canonical Smad-dependent TGF $\beta$ signaling pathway, TGF $\beta$ also activates Smad-independent non-canonical pathways. These pathways are regulated by various molecules, including Erk, JNK/p38, Rholike GTPases, PI3K/Akt, and Src [29]. Differentiation into CAFs is suppressed by reducing the activities of non-canonical pathways, even if the canonical TGF $\beta$ signaling pathway is active [30]. Exposure to TGF $\beta$ plus a non-canonical pathway inhibitor (the PI3K inhibitor LY294002, the MEK inhibitor PD98059, or the Src inhibitor PP2) significantly suppressed the increases in mRNA expression of $\alpha$ SMA, N-cadherin, and vimentin in ST2 cells (Figure 5D). In addition, knockdown of PDGFR $\beta$ attenuated phosphorylation of Akt and Erk in TGF $\beta$-treated ST2 cells (Figure 5E). Consequently, we speculate that PDGFR $\beta$ is necessary to activate noncanonical TGF $\beta$ signaling, which contributes to the differentiation of MSCs into CAFs. 


\section{TGF $\beta$ stimulation alters the functions of PDGFRß in MSCs}

PDGFRs reportedly regulate both cell proliferation and migration/differentiation [27]. We hypothesized that after MSCs have differentiated into CAFs, PDGFR $\beta$ helps to maintain CAFs via TGF $\beta$ signaling, rather than modulating cell proliferation in response to PDGF. To investigate this, we compared the level of PDGFR $\beta$ phosphorylation in response to PDGF-BB stimulation between non-stimulated MSCs and MSCs that had been stimulated with TGF $\beta$ for 72 h. The level of phosphorylated PDGFR $\beta$ following PDGF$\mathrm{BB}$ treatment was lower in TGF $\beta$-stimulated than in nonstimulated ST2 cells and human MSCs (Figures 6A and 6B), indicating that PDGF stimulates PDGFR $\beta$ to a lesser extent in CAFs than in MSCs. These results suggest that the functions of PDGFR $\beta$ in MSCs are altered upon TGF $\beta$ stimulation (Figure 6C).

\section{DISCUSSION}

This study demonstrates that PDGFR $\beta$ strongly interacts with TGF $\beta$ R upon induction of the differentiation of MSCs into CAFs by TGF $\beta$ stimulation. Moreover, the level of phosphorylated PDGFR $\beta$ was lower in CAFs than in ST2 cells following PDGF treatment (Figures 6A and 6B), indicating that PDGF stimulates PDGFR $\beta$ to a lesser extent in CAFs than in MSCs. PDGFRs promote cell proliferation
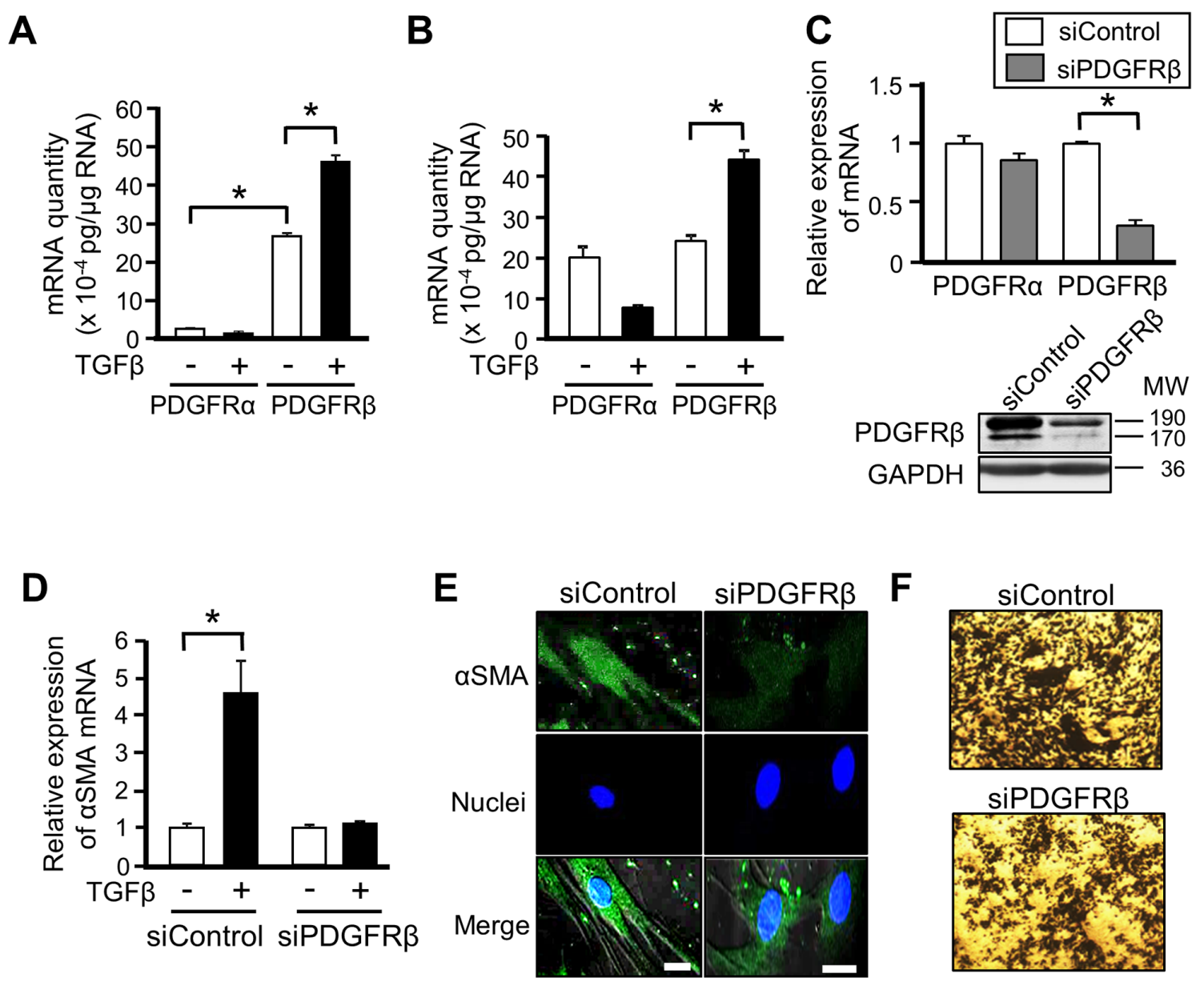

Figure 3: PDGFR $\beta$ is involved in the differentiation of mesenchymal stem cells (MSCs) into cancer-associated fibroblasts. (A, B) Absolute quantitative RT-PCR analyses were performed to measure mRNA expression of PDGFR $\alpha$ and PDGFR $\beta$ in ST2 cells (A) and human MSCs (B) stimulated with or without TGF $\beta(10 \mathrm{ng} / \mathrm{mL})$ for $48 \mathrm{~h}$. The absolute quantity of mRNA was converted to picograms. Each bar represents the mean $\pm \mathrm{SD}(\mathrm{N}=3),{ }^{*} \mathrm{P}<0.05$. (C) ST2 cells were transfected with PDGFR $\beta$-targeting or negative control siRNA for $48 \mathrm{~h}$, and then mRNA expression of PDGFR $\alpha$ and PDGFR $\beta$ was measured by quantitative RT-PCR analysis. Each bar represents the mean $\pm \mathrm{SD}(\mathrm{N}=3),{ }^{*} \mathrm{P}<0.05$. Lysates of ST2 cells transfected with the indicated siRNA were subjected to western blotting with anti-PDGFR $\beta$ and anti-GAPDH antibodies. (D) ST2 cells were transfected with PDGFR $\beta$-targeting or negative control siRNA for $48 \mathrm{~h}$ and then treated with TGF $\beta$ for $48 \mathrm{~h}$. Quantitative RT-PCR analysis was performed to measure mRNA expression of $\alpha$ SMA. Each bar represents the mean $\pm \mathrm{SD}(\mathrm{N}=3),{ }^{*} \mathrm{P}<0.05$. (E) ST2 cells described in (D) were immunostained for $\alpha$ SMA. Each scale bar indicates $20 \mu \mathrm{m}$. Nuclei were stained with TO-PRO-3 (blue). (F) ST2 cells were transfected with PDGFR $\beta$-targeting or negative control siRNA for $48 \mathrm{~h}$, treated with TGF $\beta$ for $24 \mathrm{~h}$, and co-cultured with B16 cells for $48 \mathrm{~h}$. Invaded B16 cells were stained with crystal violet (deep blue). 
upon PDGF stimulation by activating the Ras, Erk, and MAPK pathways [12, 27] and also promote cell migration and differentiation by activating the PI3K pathway [27]. The response of PDGFR $\beta$ to PDGF stimulation was decreased in CAFs (Figures 6A and 6B), suggesting that the main function of PDGFRs in CAFs is to maintain these cells rather than to modulate their proliferation. This functional change may accelerate metastasis and malignancy in tumor microenvironments.

PDGFR $\alpha$ and PDGFR $\beta$ form homodimers and heterodimers upon ligand stimulation [12]. The functions of these isoforms reportedly differ [31]. Chemotaxis is induced by homodimeric and heterodimeric PDGFR $\beta$, but not by homodimeric PDGFR $\alpha$ [31]. The expression levels of PDGFR $\alpha$ and PDGFR $\beta$ have been suggested to differ in several cell types following TGF $\beta$ stimulation; expression of PDGFR $\beta$ generally increases, while that of PDGFR $\alpha$ decreases [32, 33]. Moreover, bioinformatics screening of colorectal cancer patients demonstrated that expression of PDGFR $\beta$ is strongly correlated with that of TGF $\beta$ signaling-related genes [34]. We showed that TGF $\beta$ stimulation increased mRNA expression of PDGFR $\beta$ in ST2 cells and primary human MSCs, but decreased that of PDGFR $\alpha$ (Figures 3A and 3B). These findings imply that changes in the expression levels of PDGFR $\alpha$ and PDGFR $\beta$ alter cellular behaviors in some cell types and that PDGFR $\beta$ helps to transmit TGF $\beta$ signaling and to accelerate tumor malignancy.

Complex formation between PDGFR $\beta$ and TGF $\beta R$ was increased in ST2 cells immediately after TGF $\beta$ stimulation (Figure 5A). Therefore, the functional changes in PDGFR $\beta$ may be due to its interaction with TGF $\beta R$ and subsequent TGF $\beta$ signaling. Transmembrane receptors are mainly internalized via clathrin-mediated or caveolin-mediated endocytosis [35]. Signaling differs between these two types of internalization [36]. PDGFR $\beta$ endocytosed in a clathrin-mediated manner upon stimulation with a low concentration of PDGF promotes cell migration, whereas PDGFR $\beta$ endocytosed in a caveolin-mediated manner upon stimulation with a high concentration of PDGF accelerates cell proliferation [37]. Moreover, clathrin-mediated endocytosis of TGF $\beta R$ induces Smad activation and cell differentiation [38]. Based on these results and our findings, we speculate that complex formation between PDGFR $\beta$ and TGF $\beta$ R promotes clathrin-mediated endocytosis of both receptors in CAFs and that this promotes cell differentiation and migration.
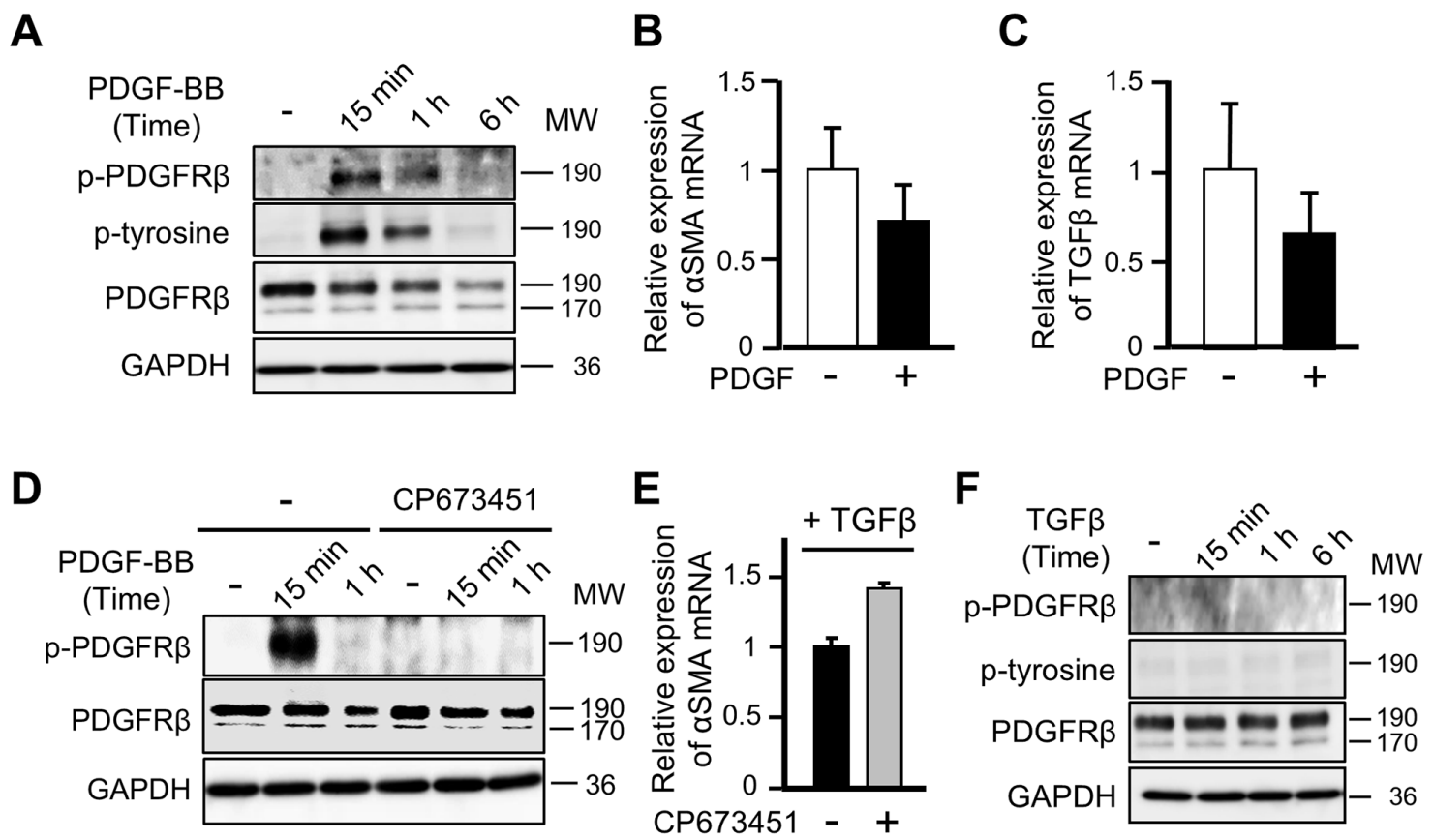

\footnotetext{
Figure 4: PDGF-PDGFR $\beta$ signaling does not affect the differentiation of mesenchymal stem cells into cancer-associated fibroblasts. (A) Lysates of ST2 cells treated with PDGF-BB $(20 \mathrm{ng} / \mathrm{mL})$ for $15 \mathrm{~min}, 1 \mathrm{~h}$, or $6 \mathrm{~h}$ were subjected to western blotting with anti-p-PDGFR $\beta$, anti-p-tyrosine, anti-PDGFR $\beta$, and anti-GAPDH antibodies. (B, C) Quantitative RT-PCR analyses were performed to measure mRNA expression of $\alpha \mathrm{SMA}(\mathrm{B})$ and TGF $\beta$ (C) in ST2 cells treated with PDGF-BB for $48 \mathrm{~h}$. Each bar represents the mean \pm SD (N=3). (D) ST2 cells were pre-treated with CP673451 (50 nM) for $2 \mathrm{~h}$ and then stimulated with PDGF-BB for $15 \mathrm{~min}$ or $1 \mathrm{~h}$. Cell lysates were subjected to western blotting with anti-p-PDGFR $\beta$, anti-PDGFR $\beta$, and anti-GAPDH antibodies. (E) ST2 cells were pre-treated with CP673451 for $1 \mathrm{~h}$ and then stimulated with TGF $\beta(10 \mathrm{ng} / \mathrm{mL})$ for 3 days. Quantitative RT-PCR analysis was performed to measure mRNA expression of $\alpha$ SMA. Each bar represents the mean $\pm \mathrm{SD}(\mathrm{N}=3)$. (F) Lysates of ST2 cells stimulated with TGF $\beta$ for $15 \mathrm{~min}, 1 \mathrm{~h}$, or $6 \mathrm{~h}$ were subjected to western blotting with anti-p-PDGFR $\beta$, anti-p-tyrosine, anti-PDGFR $\beta$, and anti-GAPDH antibodies.
} 
A

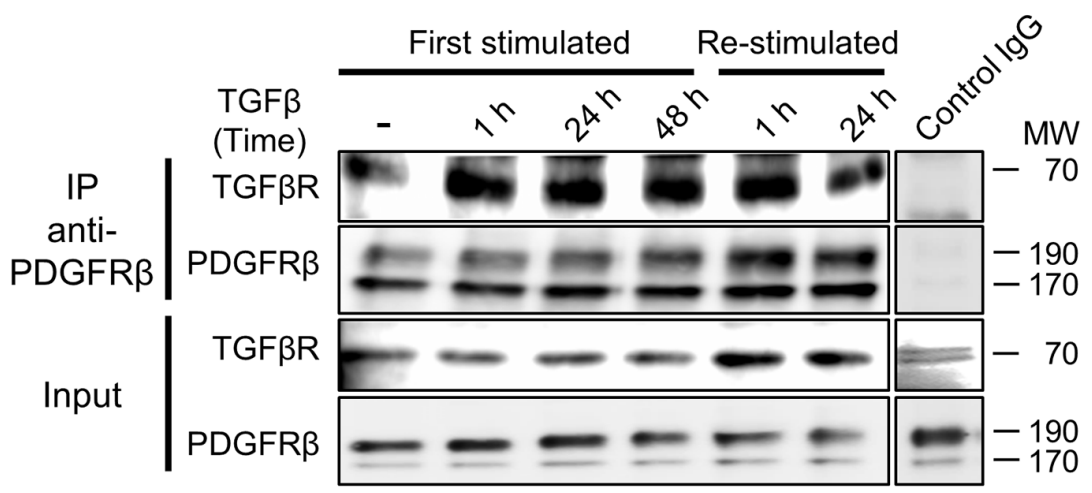

B
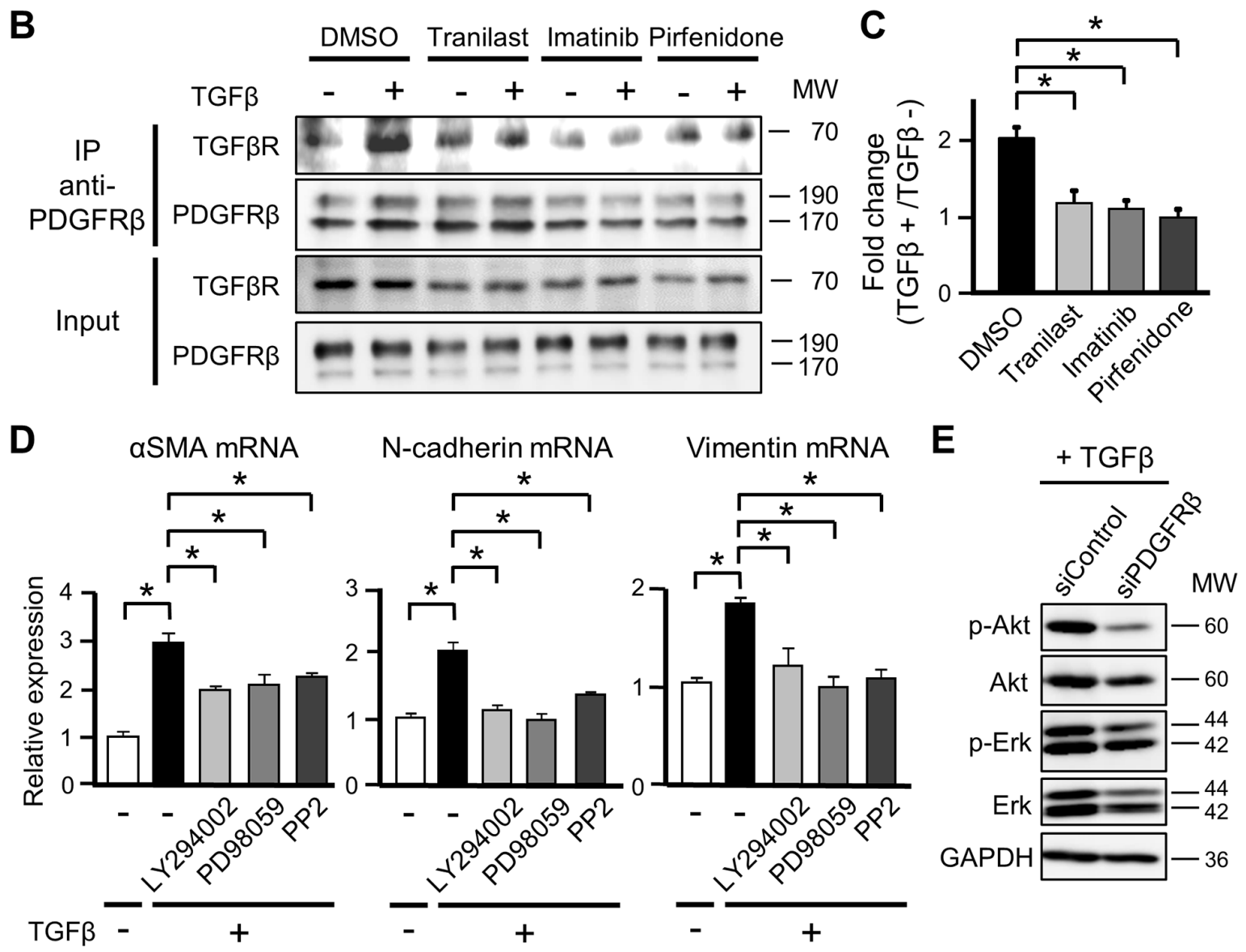

Figure 5: PDGFR interacting with TGF $\beta$ receptor (TGF $\beta$ R). (A) ST2 cells were stimulated with TGF $\beta(10 \mathrm{ng} / \mathrm{mL}$ ) for 1, 24, or $48 \mathrm{~h}$ (First stimulated), and ST2 cells stimulated with TGF $\beta$ for $48 \mathrm{~h}$ were re-stimulated with TGF $\beta$ for 1 or $24 \mathrm{~h}$ (Re-stimulated). Cell lysates were subjected to immunoprecipitation (IP) using an anti-PDGFR $\beta$ antibody or IgG isotype control. Immunoprecipitates were subjected to western blotting with anti-TGF $\beta$ R and anti-PDGFR $\beta$ antibodies. Total cell lysates were examined in parallel. (B) ST2 cells were pre-treated with tranilast $(100 \mu \mathrm{M})$, imatinib $(10 \mu \mathrm{M})$, or pirfenidone $(0.2 \mathrm{mg} / \mathrm{mL})$ for $12 \mathrm{~h}$ and then stimulated with TGF $\beta$ for $1 \mathrm{~h}$. Cell lysates were subjected to immunoprecipitation using an anti-PDGFR $\beta$ antibody. Immunoprecipitates were subjected to western blotting with anti-TGF $\beta R$ and antiPDGFR $\beta$ antibodies. Total cell lysates were examined in parallel. (C) The intensities of the bands in (B) were quantified, and the intensity of the TGF $\beta$ R band relative to that of the PDGFR $\beta$ band was determined. Fold changes in the intensity of the TGF $\beta$ R band were determined by comparing the samples obtained before and after TGF $\beta$ stimulation. Each bar represents the mean $\pm \mathrm{SD}(\mathrm{N}=3),{ }^{*} \mathrm{P}<0.05$. (D) ST2 cells were pre-treated with LY294002 $(3 \mu \mathrm{M})$, PD98059 $(20 \mu \mathrm{M})$, or PP2 $(500 \mathrm{nM})$ for $1 \mathrm{~h}$ and then stimulated with TGF $\beta$ for $48 \mathrm{~h}$. Quantitative RT-PCR analyses were performed to measure mRNA expression of $\alpha \mathrm{SMA}$, N-cadherin, and vimentin. Each bar represents the mean $\pm \mathrm{SD}$ $(\mathrm{N}=3),{ }^{*} \mathrm{P}<0.05$. (E) ST2 cells were transfected with PDGFR $\beta$-targeting or negative control siRNA for $48 \mathrm{~h}$ and then treated with TGF $\beta$ for $24 \mathrm{~h}$. Cell lysates were subjected to western blotting with anti-p-Akt, anti-Akt, anti-p-Erk, anti-Erk, and anti-GAPDH antibodies. 
Pre-treatment with tranilast, imatinib, and pirfenidone, which inhibit differentiation into CAFs, attenuated the increase in complex formation between PDGFR $\beta$ and TGF $\beta$ R in ST2 cells upon TGF $\beta$ stimulation (Figure 5B). Tranilast was reported to suppress differentiation into CAFs by inhibiting protein synthesis of TGF $\beta$ [19]; however, the detailed underlying molecular mechanism is unclear. This drug also inhibits release of chemical mediators from mast cells by suppressing $\mathrm{Ca}^{2+}$ influx and stabilizing the cell membrane [39]. We speculate that tranilast inhibits TGF $\beta$ signaling by stabilizing the plasma membrane of MSCs and decreasing membrane plasticity and complex formation between PDGFR $\beta$ and TGF $\beta$ R. Imatinib inhibits the proliferation of cancer cells by suppressing the kinase activities of c-ABL, BCR-ABL, and c-KIT [40]. Moreover, imatinib inhibits the activity PDGFR $\beta$ [41] and suppresses that of TEL-PDGFR $\beta$, which is a fusion tyrosine kinase generated in chronic myeloproliferative diseases [42]. Therefore, we speculate that imatinib suppresses complex formation between PDGFR $\beta$ and TGF $\beta$ R by changing the conformation of PDGFR $\beta$ or by competitively occupying the TGF $\beta$ R-binding site of PDGFR $\beta$. We suggest that new compounds/drugs that inhibit this interaction should be screened to suppress differentiation into CAFs.

The Smad2/3-mediated canonical and Smad2/3independent non-canonical pathways are activated upon stimulation of cells with TGF $\beta$ [28, 29]. Thus, we hypothesized that PDGFR $\beta$ and TGF $\beta$ signaling cooperatively promote the activation of $\mathrm{Smad} 2 / 3$ during the differentiation of MSCs into CAFs; however, the level of phosphorylated Smad2/3 after TGF $\beta$ stimulation did not significantly differ between control and PDGFR $\beta$ knockdown ST2 cells (data not shown). However, the
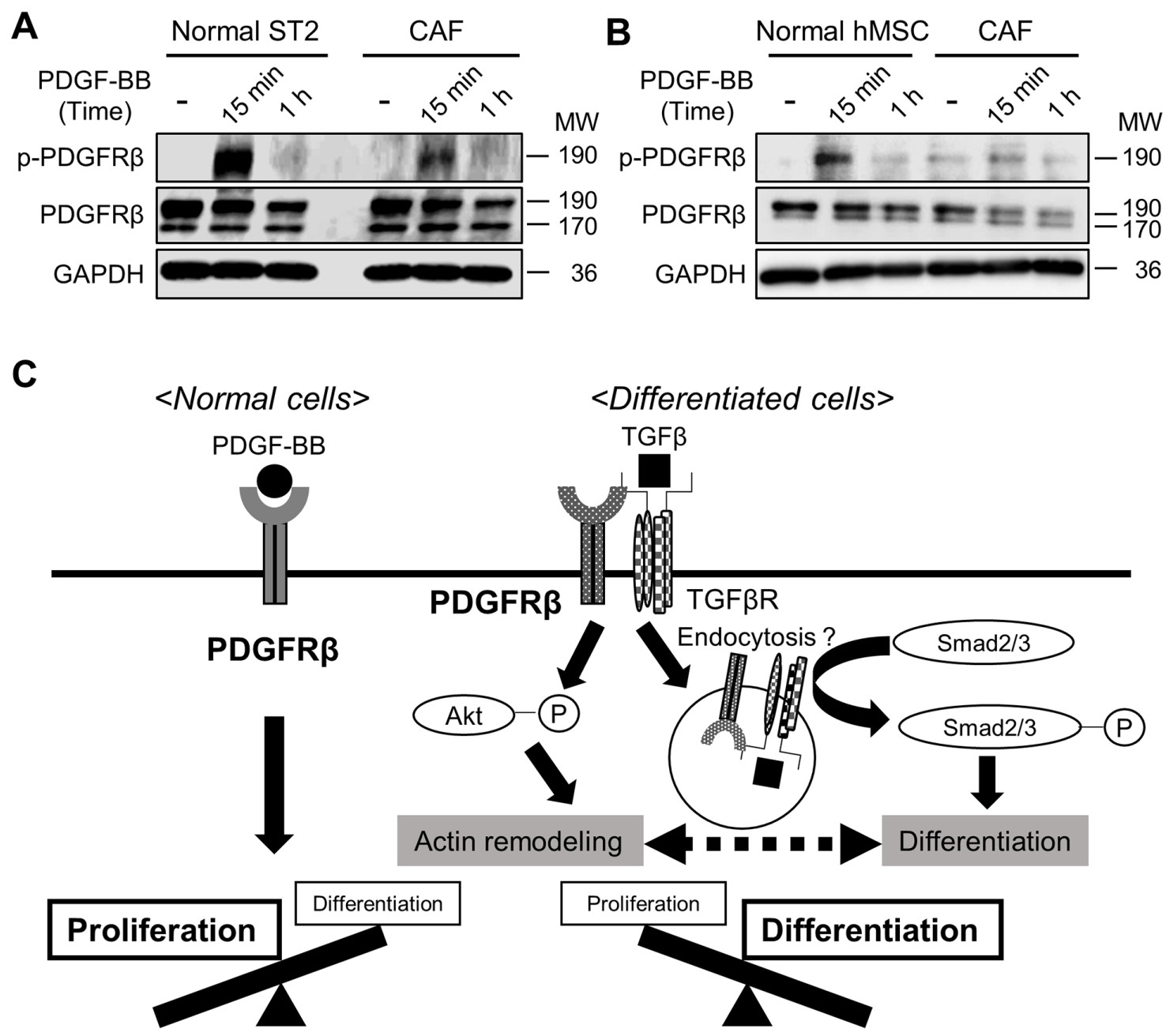

Figure 6: Stimulation with TGF $\beta$ alters the functions of PDGFR $\beta$ in mesenchymal stem cells (MSCs). (A, B) ST2 cells (A) and human MSCs (B) were pre-treated with or without TGF $\beta(10 \mathrm{ng} / \mathrm{mL})$ for $72 \mathrm{~h}$ and then stimulated with PDGF-BB (20 ng/mL) for $15 \mathrm{~min}$ or $1 \mathrm{~h}$. Cell lysates were subjected to western blotting with anti-p-PDGFR $\beta$, anti-PDGFR $\beta$, and anti-GAPDH antibodies. (C) A proposed scheme of how the functions of PDGFR $\beta$ change during differentiation into cancer-associated fibroblasts. 
levels of phosphorylated Akt and Erk, which contribute to the non-canonical TGF $\beta$ signaling pathways [29], were lower in PDGFR $\beta$-knockdown ST2 cells than in control ST2 cells upon TGF $\beta$ stimulation (Figure 5E). Akt activation was suggested to promote the migration of CAFs derived from human breast tumor tissue by inducing phosphorylation of the actin-binding protein Girdin [43]. Functional suppression of GSK3 $\beta$ by Akt or Erk reportedly stabilizes the TGF $\beta$ target gene Snail and promotes epithelial-to-mesenchymal transition $[44,45]$. Based on these findings, we speculate that non-canonical TGF $\beta$ signaling pathways control cell differentiation and migration by remodeling the actin cytoskeleton. The increase in mRNA expression of $\alpha$ SMA upon TGF $\beta$ stimulation was attenuated in ST2 cells treated with PI3K, MEK, and Src inhibitors (Figure 5D). Autophosphorylation of PDGFR $\beta$ upon PDGF stimulation activates PI3K, which promotes cell proliferation by phosphorylating Akt, mTOR, and S6K [46]. By contrast, TGF $\beta$-induced activation of Akt increases $\alpha$ SMA expression in an mTOR-independent manner via a mechanism involving upregulation of serum response factor and myocardin, which are transcription factors that regulate the expression of genes encoding actinbinding proteins [47]. These findings indicate that the behaviors of signaling factors downstream of Akt differ between proliferating and differentiating cells. Taking our results together, PDGFR $\beta$ may activate non-canonical TGF $\beta$ signaling pathways and thereby promote cell differentiation and migration, rather than cell proliferation.

CAFs in tumor microenvironments play an important role in cancer malignancy. Therefore, an approach that targets CAFs in addition to cancer cells is required to prevent tumor progression, including cancer metastasis. Here, we revealed that PDGFR $\beta$ transmits TGF $\beta$ signaling by interacting with TGF $\beta R$ during the differentiation of MSCs into CAFs and that the functions of PDGFR $\beta$ are altered in CAFs such that it promotes cell differentiation and migration rather than proliferation. Our finding that PDGFR $\beta$ is involved in TGF $\beta$ signaling will be useful for screening of compounds that inhibit differentiation into CAFs.

\section{MATERIALS AND METHODS}

\section{Reagents}

Recombinant TGF $\beta$ (Wako Pure Chemical, Tokyo, Japan) and recombinant PDGF-BB (Wako Pure Chemical) were dissolved in Milli Q water. Tranilast (Tokyo Kasei Kogyo Co., Tokyo, Japan), imatinib (Phoenix Pharmaceuticals, Belmont, CA, USA), pirfenidone (Tokyo Kasei Kogyo Co.), cromoglicate (Tokyo Kasei Kogyo Co.), bosutinib (KareBay Biochem, Ningbo, China), dasatinib (Cayman Chemical, Ann Arbor, MI, USA), CP673451 (AdooQ BioScience, Irvine, CA,
USA), LY294002 (LC Laboratories, Woburn, MA, USA), PD98059 (Wako Pure Chemical), and PP2 (Cayman Chemical) were dissolved in dimethyl sulfoxide. The final concentration of dimethyl sulfoxide in each cell culture did not exceed $0.5 \%(\mathrm{v} / \mathrm{v})$.

\section{Cell culture}

ST2 and B16F1 cells were purchased from RIKEN Cell Bank (Tsukuba, Japan) and maintained in RPMI1640 (Nacalai Tesque, Kyoto, Japan) supplemented with $10 \%$ fetal bovine serum (Life Technologies, Grand Island, NY, USA) and antibiotics (Nacalai Tesque) at $37^{\circ} \mathrm{C}$ in a humidified atmosphere of $5 \% \mathrm{CO}_{2}$ in air. Human MSCs were purchased from Lonza Japan (Tokyo, Japan) and cultured in MSCGM $^{\mathrm{TM}}$ BulletKit ${ }^{\mathrm{TM}}$ (Lonza Japan) according to the manufacturer's instructions. ST2 cells were treated with TGF $\beta$ and PDGF-BB in culture medium supplemented with $1 \%$ fetal bovine serum for $24 \mathrm{~h}$, and then the medium was replaced by fresh medium.

\section{siRNA transfection}

ST2 cells were transiently transfected with PDGFR $\beta$-targeting and control siRNAs (SIGMA, St. Louis, MO, USA) using Lipofectamine ${ }^{\mathrm{TM}} 2000$ (Life Technologies) according to the manufacturer's instructions. The sequences of the two oligonucleotide strands of the PDGFR $\beta$-targeting siRNA duplex were as follows: sense, 5'-GCG AGA AGC AAG CCU UAA UTT3 ' and anti-sense, $5^{\prime}$-AUU AAG GCU UGC UUC UCG CTT-3'.

\section{RNA isolation and quantitative real-time PCR}

Total RNA was isolated from ST2 cells using Sepasol-RNA I reagent (Nacalai Tesque) and reversetranscribed using Rever Tra Ace ${ }^{\circledR}$ qPCR RT Master mix (TOYOBO, Osaka, Japan). Alternatively, total RNA in the cell lysate was directly reverse-transcribed using a SuperPrep ${ }^{\mathrm{TM}}$ Cell Lysis \& RT Kit for qPCR (TOYOBO). The resulting cDNA was mixed with THUNDERBIRD ${ }^{\mathrm{TM}}$ quantitative real-time PCR mix (TOYOBO) and subjected to quantitative real-time PCR using a LightCycler ${ }^{\mathrm{TM}}$ Nano Real-Time PCR System (Roche, Mannheim, Germany) and the following primers: mouse aSMA forward, $5^{\prime}$ TCC TCC CTG GAG AAG AGC TAC-3' and reverse, $5^{\prime}$ TAT AGG TGG TTT CGT GGA TGC-3'; human $\alpha$ SMA forward, 5'-GAC AAT GGC TCT GGG CTC TG-3' and reverse, 5'-TGC CAT GTT CTA TCG GGT AC-3'; mouse $\mathrm{N}$-cadherin forward, $5^{\prime}$-AGC GCA GTC TTA CCG AAG G-3' and reverse, 5'-GGC TCG CTG CTT TCA TAC TGA AC-3'; human N-cadherin forward, 5'-ACA GTG GCC ACC TAC AAA GG-3' and reverse, 5'-CCG AGA TGG GGT TGA TAA TG-3'; mouse vimentin forward, $5^{\prime}$-CGG AAA GTG GAA TCC TTG C-3' and reverse, 5' CAC ATC GAT CTG GAC ATG CTG-3'; human vimentin 
forward, 5'-GAG AAC TTT GCC GTT GAA GC-3' and reverse, $5^{\prime}$-GCT TCC TGT AGG TGG CAA TC-3'; TGF $\beta$ forward, 5'-CAA GGG CTA CCA TGC CAA C-3' and reverse, 5'-AGG GCC AGG ACC TTG CTG-3'; mouse PDGFR $\alpha$ forward, 5'-TTA TCG AGT CAA TCA GCC CC-3' and reverse, 5'-TTG AGC ATC TTC ACA GCC AC-3'; human PDGFR $\alpha$ forward, 5'-CCT GGT CTT AGG CTG TCT TC-3' and reverse, 5'-GCC AGC TCA CTT CAC TCT CC-3'; mouse PDGFR $\beta$ forward, $5^{\prime}-\mathrm{CCG}$ GAA CAA ACA CAC CTT CT-3' and reverse, 5'-TAT CCA TGT AGC CAC CGT CA-3'; human PDGFR $\beta$ forward, 5'-ACA CGG GAG AAT ACT TTT GC-3' and reverse, 5'-GTT CCT CGG CAT CAT TAG GG-3'; and 18S ribosomal RNA forward, 5'-CGC CGC TAG AGG TGA AAT TC-3' and reverse, 5'-TTG GCA AAT GCT TTC GCT C-3'. The reaction was performed at $95^{\circ} \mathrm{C}$ for $60 \mathrm{~s}$, followed by 40 cycles at $95^{\circ} \mathrm{C}$ for $10 \mathrm{~s}$ and $60^{\circ} \mathrm{C}$ for $60 \mathrm{~s}$. Relative mRNA expression was calculated after normalization against $18 \mathrm{~S}$ ribosomal RNA expression. The sequences amplified by quantitative real-time PCR were inserted into the pDONR221 plasmid (Life Technologies) for absolute quantification of the cDNA copy number.

\section{Immunostaining}

Cells were fixed in PBS containing 4\% formaldehyde, permeabilized in PBS containing $0.1 \%$ Triton X-100, immunostained with a rabbit anti- $\alpha$ SMA primary antibody (Abcam, Cambridge, UK), and labeled with a secondary antibody conjugated with an Alexa Fluor dye (Life Technologies). Nuclei were stained with TO-PRO-3 iodide (Life Technologies). Fluorescence was detected using a Carl Zeiss LSM700 laser scanning confocal microscope (Prenzlauer, Berlin, Germany).

\section{Enzyme-linked immunosorbent assay (ELISA)}

The TGF $\beta$ protein level in the culture medium was measured using the DuoSet ELISA Development System (R\&D Systems Inc., Minneapolis, MN, USA) according to the manufacturer's instructions.

\section{Transwell co-culture system}

B16 and ST2 cells were seeded into the upper or lower chamber of a transwell culture plate $\left(\right.$ Falcon $^{\circledR}$, Corning Inc., Corning, NY, USA) for non-contact coculture. To collect mRNA from B16 cells, ST2 cells were seeded into the upper chamber, treated with TGF $\beta$ for 24 $\mathrm{h}$, and then co-cultured with B16 cells seeded into the lower chamber for 7 days. To evaluate invasion of B16 cells, ST2 cells were seeded into the lower chamber, treated with TGF $\beta$ for $24 \mathrm{~h}$, and then co-cultured for 24 or $48 \mathrm{~h}$ with B16 cells seeded into the upper chamber, which was coated with Matrigel (Corning Inc). Non-invaded cells were removed using Accutase ${ }^{\mathrm{TM}}$ (Nacalai Tesque), and then B16 cells that had invaded through the Matrigel were fixed in PBS containing 4\% formaldehyde and stained with crystal violet (Wako Pure Chemical) prepared in methanol.

\section{Immunoprecipitation}

Cells were lysed on ice in lysis buffer, which comprised $20 \mathrm{mM}$ Tris- $\mathrm{HCl}$ (pH 7.4), $150 \mathrm{mM} \mathrm{NaCl}$, $5 \%$ glycerol, $1 \%$ NP-40, and a protease inhibitor cocktail (Roche). Samples were incubated overnight at $4^{\circ} \mathrm{C}$ with an anti-PDGFR $\beta$ antibody (Cell Signaling Technologies, Beverly, MA, USA) or control rabbit IgG (Wako Pure Chemical). Immunoprecipitated proteins were adsorbed onto immobilized protein G-coated magnetic beads (Merck Millipore, Berlin, Germany) and eluted with $0.1 \mathrm{M}$ glycine- $\mathrm{HCl}$ ( $\mathrm{pH} 3.0)$, which was subsequently neutralized with $0.5 \mathrm{M}$ Tris- $\mathrm{HCl}$ ( $\mathrm{pH} 8.0$ ) containing $1.5 \mathrm{M} \mathrm{NaCl}$.

\section{Western blotting}

Cells were lysed on ice in lysis buffer, which comprised PBS (pH 7.4) containing 1\% Triton X-100 and protease and phosphatase inhibitor cocktails (Roche). Identical amounts of protein from each sample and immunoprecipitate were separated by SDS-PAGE and transferred to PVDF membranes (Merck Millipore). The membranes were blocked and probed with primary antibodies specific for $\mathrm{p}-\mathrm{PDGFR} \beta, \operatorname{PDGFR} \beta$, p-tyrosine, p-Akt, Akt, p-Erk1/2, Erk, and GAPDH (all from Cell Signaling Technologies) as well as TGF $\beta R$ (Abcam). Immunolabeled proteins were detected using HRPlabeled secondary antibodies (Santa Cruz Biotechnology, Santa Cruz, CA, USA) and ECL Prime detection reagents (GE Healthcare, Buckinghamshire, UK). Signals were visualized using the ImageQuant LAS 4000 system (GE Healthcare).

\section{Statistical analysis}

All data are expressed as the mean $\pm \mathrm{SD}$ or the mean \pm SE of at least three independent experiments, unless indicated otherwise. Statistical analyses were performed using the Student's $t$ test or an analysis of variance followed by the Bonferroni test, where applicable. A $p$ value of $<0.05$ was considered significant.

\section{Abbreviations}

$\alpha$ SMA, $\alpha$-smooth muscle actin; CAF, cancerassociated fibroblast; ELISA, enzyme-linked immunosorbent assay; MAPK, mitogen-activated protein kinase; MSC, mesenchymal stem cell; PDGF, plateletderived growth factor; PDGFR, PDGF receptor; PI3K, phosphoinositide 3-kinase; TGF $\beta$, transforming growth factor $\beta$; TGF $\beta$ R, TGF $\beta$ receptor; TKI, tyrosine kinase inhibitor. 


\section{Author contributions}

K.A. performed the experiments, analyzed the data, and wrote the manuscript. K.I. wrote and revised the manuscript. S.A. designed the study, performed the experiments, analyzed the data, and wrote and revised the manuscript.

\section{ACKNOWLEDGMENTS}

We thank Chiba University, Japan, for supporting this project.

\section{CONFLICTS OF INTEREST}

The authors have no conflicts of interest to declare.

\section{FUNDING}

This work was supported by the Program for Dissemination of the Tenure-Track System in Japan funded by the Ministry of Education, Culture, Sports, Science, and Technology and by a Grant-in-Aid for Young Scientists (B) (16K18932) from the Japan Society for the Promotion of Science.

\section{REFERENCES}

1. Inaba $\mathrm{H}$, Greaves $\mathrm{M}$, Mullighan CG. Acute lymphoblastic leukaemia. Lancet. 2013; 381:1943-1955.

2. Hanahan D, Coussens LM. Accessories to the crime: functions of cells recruited to the tumor microenvironment. Cancer Cell. 2012; 21:309-322.

3. Elenbaas B, Weinberg RA. Heterotypic signaling between epithelial tumor cells and fibroblasts in carcinoma formation. Exp Cell Res. 2001; 264:169-184.

4. Gascard P, Tlsty TD. Carcinoma-associated fibroblasts: orchestrating the composition of malignancy. Genes Dev. 2016; 30:1002-1019.

5. Kalluri R, Zeisberg M. Fibroblasts in cancer. Nat Rev Cancer. 2006; 6:392-401.

6. Wiseman BS, Werb Z. Stromal effects on mammary gland development and breast cancer. Science. 2002; 296:1046-1049.

7. Cirri P, Chiarugi P. Cancer associated fibroblasts: the dark side of the coin. Am J Cancer Res. 2011; 1:482-497.

8. Desmouliere A, Guyot C, Gabbiani G. The stroma reaction myofibroblast: a key player in the control of tumor cell behavior. Int J Dev Biol. 2004; 48:509-517.

9. Denys H, Derycke L, Hendrix A, Westbroek W, Gheldof A, Narine K, Pauwels P, Gespach C, Bracke M, De Wever O. Differential impact of TGF-beta and EGF on fibroblast differentiation and invasion reciprocally promotes colon cancer cell invasion. Cancer Lett. 2008; 266:263-274.
10. Yao Q, Cao S, Li C, Mengesha A, Kong B, Wei M. MicroRNA-21 regulates TGF-beta-induced myofibroblast differentiation by targeting PDCD4 in tumor-stroma interaction. Int J Cancer. 2011; 128:1783-1792.

11. Massague J. How cells read TGF-beta signals. Nat Rev Mol Cell Biol. 2000; 1:169-178.

12. Heldin $\mathrm{CH}$, Eriksson U, Ostman A. New members of the platelet-derived growth factor family of mitogens. Arch Biochem Biophys. 2002; 398:284-290.

13. Ostman A, Heldin CH. PDGF receptors as targets in tumor treatment. Adv Cancer Res. 2007; 97:247-274.

14. Ostman A. PDGF receptors-mediators of autocrine tumor growth and regulators of tumor vasculature and stroma. Cytokine Growth Factor Rev. 2004; 15:275-286.

15. Abramsson A, Lindblom P, Betsholtz C. Endothelial and nonendothelial sources of PDGF-B regulate pericyte recruitment and influence vascular pattern formation in tumors. J Clin Invest. 2003; 112:1142-1151.

16. Cao R, Bjorndahl MA, Religa P, Clasper S, Garvin S, Galter D, Meister B, Ikomi F, Tritsaris K, Dissing S, Ohhashi T, Jackson DG, Cao Y. PDGF-BB induces intratumoral lymphangiogenesis and promotes lymphatic metastasis. Cancer Cell. 2004; 6:333-345.

17. Paulsson J, Sjoblom T, Micke P, Ponten F, Landberg G, Heldin CH, Bergh J, Brennan DJ, Jirstrom K, Ostman A. Prognostic significance of stromal platelet-derived growth factor beta-receptor expression in human breast cancer. Am J Pathol. 2009; 175:334-341.

18. Koda A, Nagai H, Watanabe S, Yanagihara Y, Sakamoto $\mathrm{K}$. Inhibition of hypersensitivity reactions by a new drug, $\mathrm{N}\left(3^{\prime}, 4^{\prime}\right.$-dimethoxycinnamoyl) anthranilic acid (N-5'). J Allergy Clin Immunol. 1976; 57:396-407.

19. Ohshio Y, Hanaoka J, Kontani K, Teramoto K. Tranilast inhibits the function of cancer-associated fibroblasts responsible for the induction of immune suppressor cell types. Scand J Immunol. 2014; 80:408-416.

20. Demetri GD, von Mehren M, Blanke CD, Van den Abbeele AD, Eisenberg B, Roberts PJ, Heinrich MC, Tuveson DA, Singer S, Janicek M, Fletcher JA, Silverman SG, Silberman SL, et al. Efficacy and safety of imatinib mesylate in advanced gastrointestinal stromal tumors. N Engl J Med. 2002; 347:472-480.

21. Aono Y, Nishioka Y, Inayama M, Ugai M, Kishi J, Uehara $\mathrm{H}$, Izumi $\mathrm{K}$, Sone $\mathrm{S}$. Imatinib as a novel antifibrotic agent in bleomycin-induced pulmonary fibrosis in mice. Am J Respir Crit Care Med. 2005; 171:1279-1285.

22. Mueller L, Goumas FA, Himpel S, Brilloff S, Rogiers X, Broering DC. Imatinib mesylate inhibits proliferation and modulates cytokine expression of human cancer-associated stromal fibroblasts from colorectal metastases. Cancer Lett. 2007; 250:329-338.

23. Azuma A. Pirfenidone treatment of idiopathic pulmonary fibrosis. Ther Adv Respir Dis. 2012; 6:107-114. 
24. Conte E, Gili E, Fagone E, Fruciano M, Iemmolo M, Vancheri C. Effect of pirfenidone on proliferation, TGFbeta-induced myofibroblast differentiation and fibrogenic activity of primary human lung fibroblasts. Eur J Pharm Sci. 2014; 58:13-19.

25. Pittenger MF, Mackay AM, Beck SC, Jaiswal RK, Douglas R, Mosca JD, Moorman MA, Simonetti DW, Craig S, Marshak DR. Multilineage potential of adult human mesenchymal stem cells. Science. 1999; 284:143-147.

26. Puttini M, Coluccia AM, Boschelli F, Cleris L, Marchesi E, Donella-Deana A, Ahmed S, Redaelli S, Piazza R, Magistroni V, Andreoni F, Scapozza L, Formelli F, Gambacorti-Passerini C. In vitro and in vivo activity of SKI-606, a novel Src-Abl inhibitor, against imatinibresistant Bcr-Abl+ neoplastic cells. Cancer Res. 2006; 66:11314-11322.

27. Tallquist M, Kazlauskas A. PDGF signaling in cells and mice. Cytokine Growth Factor Rev. 2004; 15:205-213.

28. Xu P, Liu J, Derynck R. Post-translational regulation of TGF-beta receptor and Smad signaling. FEBS Lett. 2012; 586:1871-1884.

29. Zhang YE. Non-Smad pathways in TGF-beta signaling. Cell Res. 2009; 19:128-139.

30. Kattla JJ, Carew RM, Heljic M, Godson C, Brazil DP. Protein kinase B/Akt activity is involved in renal TGFbeta1-driven epithelial-mesenchymal transition in vitro and in vivo. Am J Physiol Renal Physiol. 2008; 295:F215-225.

31. Ronnstrand L, Heldin CH. Mechanisms of platelet-derived growth factor-induced chemotaxis. Int J Cancer. 2001; 91:757-762.

32. Bonner JC, Badgett A, Lindroos PM, Osornio-Vargas AR. Transforming growth factor beta 1 downregulates the platelet-derived growth factor alpha-receptor subtype on human lung fibroblasts in vitro. Am J Respir Cell Mol Biol. 1995; 13:496-505.

33. Pinzani M, Gentilini A, Caligiuri A, De Franco R, Pellegrini G, Milani S, Marra F, Gentilini P. Transforming growth factor-beta 1 regulates platelet-derived growth factor receptor beta subunit in human liver fat-storing cells. Hepatology. 1995; 21:232-239.

34. Steller EJ, Raats DA, Koster J, Rutten B, Govaert KM, Emmink BL, Snoeren N, van Hooff SR, Holstege FC, Maas C, Borel Rinkes IH, Kranenburg O. PDGFRB promotes liver metastasis formation of mesenchymal-like colorectal tumor cells. Neoplasia. 2013; 15:204-217.

35. Le Roy C, Wrana JL. Clathrin- and non-clathrin-mediated endocytic regulation of cell signalling. Nat Rev Mol Cell Biol. 2005; 6:112-126.
36. Polo S, Di Fiore PP. Endocytosis conducts the cell signaling orchestra. Cell. 2006; 124:897-900.

37. De Donatis A, Comito G, Buricchi F, Vinci MC, Parenti A, Caselli A, Camici G, Manao G, Ramponi G, Cirri P. Proliferation versus migration in platelet-derived growth factor signaling: the key role of endocytosis. J Biol Chem. 2008; 283:19948-19956.

38. Di Guglielmo GM, Le Roy C, Goodfellow AF, Wrana JL. Distinct endocytic pathways regulate TGF-beta receptor signalling and turnover. Nat Cell Biol. 2003; 5:410-421.

39. Komatsu H, Kojima M, Tsutsumi N, Hamano S, Kusama H, Ujiie A, Ikeda S, Nakazawa M. Study of the mechanism of inhibitory action of tranilast on chemical mediator release. Jpn J Pharmacol. 1988; 46:43-51.

40. Druker BJ, Talpaz M, Resta DJ, Peng B, Buchdunger E, Ford JM, Lydon NB, Kantarjian H, Capdeville R, OhnoJones S, Sawyers CL. Efficacy and safety of a specific inhibitor of the BCR-ABL tyrosine kinase in chronic myeloid leukemia. N Engl J Med. 2001; 344:1031-1037.

41. Druker BJ, Tamura S, Buchdunger E, Ohno S, Segal GM, Fanning S, Zimmermann J, Lydon NB. Effects of a selective inhibitor of the Abl tyrosine kinase on the growth of BcrAbl positive cells. Nat Med. 1996; 2:561-566.

42. Gunby RH, Cazzaniga G, Tassi E, Le Coutre P, Pogliani E, Specchia G, Biondi A, Gambacorti-Passerini C. Sensitivity to imatinib but low frequency of the TEL/PDGFRbeta fusion protein in chronic myelomonocytic leukemia. Haematologica. 2003; 88:408-415.

43. Yamamura Y, Asai N, Enomoto A, Kato T, Mii S, Kondo Y, Ushida K, Niimi K, Tsunoda N, Nagino M, Ichihara $\mathrm{S}$, Furukawa K, Maeda K, et al. Akt-Girdin signaling in cancer-associated fibroblasts contributes to tumor progression. Cancer Res. 2015; 75:813-823.

44. Lan A, Qi Y, Du J. Akt2 mediates TGF-beta1-induced epithelial to mesenchymal transition by deactivating GSK3beta/snail signaling pathway in renal tubular epithelial cells. Cell Physiol Biochem. 2014; 34:368-382.

45. Nagarajan D, Melo T, Deng Z, Almeida C, Zhao W. ERK/ GSK3beta/Snail signaling mediates radiation-induced alveolar epithelial-to-mesenchymal transition. Free Radic Biol Med. 2012; 52:983-992.

46. Gao N, Zhang Z, Jiang BH, Shi X. Role of PI3K/AKT/ mTOR signaling in the cell cycle progression of human prostate cancer. Biochem Biophys Res Commun. 2003; 310:1124-1132.

47. Abdalla M, Goc A, Segar L, Somanath PR. Akt1 mediates alpha-smooth muscle actin expression and myofibroblast differentiation via myocardin and serum response factor. $\mathrm{J}$ Biol Chem. 2013; 288:33483-33493. 